\title{
Pineapple bacilliform CO virus: Diversity, Detection, Distribution, and Transmission
}

D. M. Sether, M. J. Melzer, W. B. Borth, and J. S. Hu, University of Hawaii at Manoa, Department of Plant and Environmental Protection Sciences, Honolulu 96822-2232

\begin{abstract}
Sether, D. M., Melzer, M. J., Borth, W. B., and Hu, J. S. 2012. Pineapple bacilliform CO virus: Diversity, detection, distribution, and transmission. Plant Dis. 96:1798-1804.

Members of the genus Badnavirus (family Caulimovirdae) have been identified in dicots and monocots worldwide. The genome of a pineapple badnavirus, designated Pineapple bacilliform $\mathrm{CO}$ virus-HI1 (PBCOV-HI1), and nine genomic variants (A through $\mathrm{H}$ ) were isolated and sequenced from pineapple, Ananas comosus, in Hawaii. The 7,451-nucleotide genome of PBCOV-HI1 possesses three open reading frames (ORFs) encoding putative proteins of 20 (ORF1), 15 (ORF2), and 211 (ORF3) kDa. ORF3 encodes a polyprotein that includes a putative movement protein and viral aspartyl proteinase, reverse transcriptase, and RNase $\mathrm{H}$ regions. Three distinct groups of putative

endogenous pineapple pararetroviral sequences and Metaviridae-like retrotransposons encoding long terminal repeat, reverse-transcriptase, $\mathrm{RNase} \mathrm{H}$, and integrase regions were also identified from the pineapple genome. Detection assays were developed to distinguish PBCOV-HI1 and genomic variants, putative endogenous pararetrovirus sequences, and Ananas Metaviridae sequences also identified in pineapple. PBCOV-HI1 incidences in two commercially grown pineapple hybrids, PRI 73-114 and PRI 73-50, was 34 to $68 \%$. PBCOV-HI1 was transmitted by gray pineapple mealybugs, Dysmicoccus neobrevipes, to pineapple.
\end{abstract}

Badnaviruses are pararetroviruses that infect many economically and culturally important temperate and tropical crops, including sugarcane, banana, citrus, taro, sweet potato, cacao, yam, pineapple, and dracaena, and can infect angiosperms and gymnosperms $(1,5,9,11,19,22,32,33,37,41)$. Badnaviruses are members of the family Caulimoviridae and have bacilliform-shaped virions approximately $30 \mathrm{~nm}$ in width and 60 to $900 \mathrm{~nm}$ in length that encapsidate a reverse transcribing, circular, noncovalently closed double-stranded (ds)DNA genome of approximately 7 to $9 \mathrm{kbp}$ (4). Badnavirses lack the translational transactivator protein found in other caulimoviruses $(4,16)$. Fully characterized badnaviruses have at least three open reading frames (ORFs) which includes the type member, Commelina yellow mottle virus, while Taro bacilliform virus (TaBV), Cacao swollen shoot virus (CSSV), Citrus yellow mosaic virus (CYMV), and Dracaena mottle virus (DrMV) contain $4,5,6$, and 7 ORFs, respectively $(11,15,25,37,43)$. Badnaviruses, in general, are genomically and serologically highly variable $(6,18,23,26,34,44)$.

The symptoms of badnavirus infections vary with host and virus and can include mosaic, chlorosis, vein banding, and stunting. Symptoms may be seasonal or can disappear shortly after infection. A clear association between symptoms and badnavirus infection of pineapple has not been shown (5). Several badnavirus infections have been known to have synergistic effects with other unrelated viruses. Dual infections of badnaviruses such as Discorea bacilliform virus (DBV) with a potyvirus or cucumovirus (29), TaBV with a putative rhabdovirus $(2,43)$, or Gooseberry vein banding associated virus $(\mathrm{GVBaV})$ infection with a rhabdovirus or

Corresponding author: D. M. Sether, E-mail: diane_sether@fws.gov

Current address of D. M. Sether: U.S. Fish and Wildlife Service, Honolulu, HI 96850-3122.

The findings and conclusions in this article are those of the authors and do not necessarily represent the views of the U.S. Fish and Wildlife Service.

Accepted for publication 27 June 2012.

http://dx.doi.org/10.1094/PDIS-08-11-0718-RE

(C) 2012 The American Phytopathological Society a clostero-like virus (19) cause more severe symptoms and more yield damage than a single infection by either virus.

The term "retro element" can be applied to an entity that uses reverse transcription as a mechanism for replication (31). Retrotransposons can be divided into two subtypes: long terminal repeat (LTR) and non-LTR. The LTR type can be divided into two families, Pseudoviridae and Metaviridae. The Ty1-copia type is typical of the family Pseudoviridae, which occurs mostly in plants. The family Metaviridae is characterized by Ty3-gypsy-type retrotransposons (3). The genome structure of this family resembles that of retroviruses, where the integrase domain is downstream of the reverse-transcriptase region (28). Integration is obligatory for replication. In contrast, members of the family Caulimoviridae do not encode for an integrase and do not have LTRs (31). These pararetroviruses do not require integration of the viral genome into the host genome to complete the replication cycle. Despite this nonintegrative replication cycle, integrated sequences identical to the episomal sequences of viruses belonging to several genera of the family Caulimoviridae, including banana streak badnaviruses $(7,27)$ Tobacco vein clearing virus, a Solendovirus $(8,21)$, rice tungroviruses (23), and petunia vein clearing petuvirus (30), have been identified. These integrated counterparts to Caulimoviridae members have been designated as endogenous pararetroviruses $(7,10,17,24,27,30)$.

Our primary objectives were to characterize the badnaviruses present in Hawaiian-grown pineapple, determine diversity, develop detection assays, and evaluate field distribution and mealybug transmissibility. During this study, we also identified additional sequences encoding reverse-transcriptase regions which we have partially characterized to better understand their possible function.

\section{Materials and Methods}

Virus purification. Pineapple (Ananas comosus (L.) Merr.) 'Champaka Smooth Cayenne' and 'PRI 37-114' from Hawaii were used for nucleic acid and virus extraction. Leaf material was removed from plants, powdered with liquid nitrogen in a commercial coffee grinder, and stored at $-20^{\circ} \mathrm{C}$. Powdered leaf material was combined (1:5) with purification buffer $(0.5 \mathrm{M}$ Tris- $\mathrm{HCl}, \mathrm{pH} 8.4$; $0.5 \% \mathrm{Na}_{2} \mathrm{SO}_{3}$; and $10 \mathrm{mM} \mathrm{Mg} \mathrm{SO}_{4}$ ), and stirred overnight at $4{ }^{\circ} \mathrm{C}$ $(13,14)$. The liquid was filtered through several layers of cheesecloth and Triton X-100 was added to a final concentration of $2 \%$. 
After mixing, the solution was centrifuged at $12,000 \times g$ and layered over $30 \%$ sucrose pads in $100 \mathrm{mM}$ phosphate buffer, $\mathrm{pH} 7.2$. The extract was centrifuged for $66 \mathrm{~min}$ at $32,000 \times \mathrm{g}$. The pellet was resuspended in $100 \mathrm{mM}$ potassium phosphate, $\mathrm{pH} 7.2$, spun briefly to remove large debris, and passed through a second $30 \%$ sucrose pad as previously described. The pellet was resuspended in

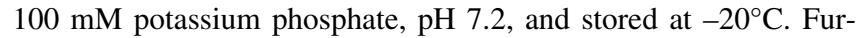
ther purification was conducted as previously described $(13,14)$. Briefly, the virus resuspension was layered over a $\mathrm{Cs}_{2} \mathrm{So}_{4}$ step gradient consisting of $20,12.5$, and $10 \% \mathrm{Cs}_{2} \mathrm{So}_{4}$ layers and centrifuged at $100,000 \times g$ for $3 \mathrm{~h}$. Fractions were collected with a density gradient fractionator. Selected fractions were pooled, dialyzed, and pelleted. Pellets were resuspended in $100 \mathrm{mM}$ Tris-HCL, pH 8.0 , and stored at $-80^{\circ} \mathrm{C}$.

Extraction of viral DNA. Viral resuspensions described above were subjected to DNase I treatments as follows: $35 \mu \mathrm{l}$ of virus resuspension, $5 \mu \mathrm{l}$ of $10 \times$ DNase I buffer, and $10 \mu \mathrm{l}$ of DNase I (1 $\mu / \mu \mathrm{l})$ were incubated at room temperature for $60 \mathrm{~min}$. Reaction was inactivated by adding $5 \mu \mathrm{l}$ of $25 \mathrm{mM}$ EDTA. Virions were disrupted with the addition of Proteinase $\mathrm{K}(1 \mathrm{mg} / \mathrm{ml})$ and $0.5 \%$ sodium dodecyl sulfate in a $100 \mathrm{mM}$ Tris buffer $(\mathrm{pH} 8.0)$ containing $2 \mathrm{mM}$ $\mathrm{CaCl}_{2}$ for $1 \mathrm{~h}$ at $37^{\circ} \mathrm{C}$. The mixture was extracted two times in phenol/chloroform/isoamyl alcohol (25:24:1), ethanol precipitated, and viral DNA resuspended in water.

Extraction of total DNA from plants. Leaf tissue (approximately $100 \mathrm{mg}$ ) was powdered in liquid nitrogen and total DNA was purified with DNeasy Plant Mini Kits (Qiagen) as per manufacturer's instructions and stored at $-80^{\circ} \mathrm{C}$.

Cloning and sequencing. Initial polymerase chain reaction (PCR) detection reactions were conducted with degenerate oligonucleotide 573 and 572 based on Badna-1A and Badna-4 (21), respectively, using the conserved reverse transcriptase (RT) and RNase $\mathrm{H}$ regions of badnaviruses. PCR conditions with primers and BIO-X-ACT Long Mix (Bioline) were as follows: $96^{\circ} \mathrm{C}$ for $4 \mathrm{~min}$; 40 cycles of $95^{\circ} \mathrm{C}$ for $1 \mathrm{~min}, 52^{\circ} \mathrm{C}$ for $1 \mathrm{~min}$, and $72^{\circ} \mathrm{C}$ for $1 \mathrm{~min}$; followed by $72^{\circ} \mathrm{C}$ for $10 \mathrm{~min}$. Amplicons of the expected size were cloned into pGEM-T-Easy (Promega Corp.). Clones were sequenced at the University of Hawaii's Greenwood Molecular Biology Facility or Advanced Studies of Genomics, Proteomics, and Bioinformatics laboratory. Sequencing of regions outside of the RT and RNase $\mathrm{H}$ regions was conducted using specific primers paired with primers composed of six random hexamers at the $3^{\prime}$ end or assorted degenerate primers based on conserved motifs of other badnaviruses. These primer combinations were used in PCR with BIO-X-ACT Long Mix with 3- to 5-min $72^{\circ} \mathrm{C}$ elongation cycles. DNeasy Plant Mini kits were used to purify closed-circle DNA from plant nuclei for sequencing the $5^{\prime}$ untranslated region (UTR). Facing primers were designed approximately 400 bases $5^{\prime}$ and $3^{\prime}$ of sequenced overlapping areas and used in PCR. The amplicons were cloned, sequenced, and compared with previous sequences with the web-based sequence analysis software SeqWeb, ver. 2 .

Phylogenetic analyses. Nucleotide sequences were compared with the nonredundant amino acid sequence database at the National Center for Biotechnology Information website using the BLASTX algorithm. Homologies were determined with SeqWeb GAP using a BLOSUM 65 matrix. Amino acid sequences were aligned with ClustalX (39), with pairwise alignment parameters of 35 for gap opening penalty and 0.75 for the gap extension penalty and utilizing Gonet protein weight matrix. Multiple alignment parameters were gap opening penalty of 15 and a gap extension penalty of 0.3 . Divergent sequence delay was set to $25 \%$. Neighbor-joined trees were created and bootstrapped (1,000 replicates) with PAUP 4.0 (38). GenBank accessions used for comparisons were as follows: Banana streak VN virus (BSVNV, YP_233110), Banana streak MY virus (BSMYV, YP_224289), Banana streak GF virus (BSGFV, YP_233107), Banana streak OL virus (BSOLV, NP_056728), Blueberry red ringspot virus (BRRSV, NP_395469), Bougainville chlorotic vein banding virus (BCVBV, YP_002321513), CSSV (NP_041734), Cassava vein mosaic virus (CsVMV, NP_056848), Carnation etched ring virus (CERV, NP_612577),
Cauliflower mosaic virus (CaMV, NP_056728), Cestrum yellow leaf curling virus (CYLCV, NP_861410), CYMV (NP_569153), Commelina yellow mosaic virus (ComYMV, NP_039820), Cycad leaf necrosis virus (CLNV, YP_002117531), Dahlia mosaic virus (DMV, ABW81763), DrMV (YP_610965), Eupatorium vein clearing virus (EVCV, YP_001931967), Figwort mosaic virus (FMV, NP_619548), Horseradish latent virus (HRLV, AAW56089), Kalanchoё top-spotting virus (KTSV NP_777317), Lamium leaf distortion virus (LLDV, YP_001931961), Lucky bamboo bacilliform virus (LBBV, YP_001293182), Mirabilis mosaic virus (MiMV, NP_659397), Peanut chlorotic streak virus (PCSV, NP_042513), Petunia vein clearing virus (PVCV, NP_127504), Pineapple bacilliform CO viruses (PBCOVs, YP_003987456; EU377666, EU377664, EU377669, EU377671, EU377667, and EU377672), Pineapple bacilliform ER viruses (PBErV, EU377672 and EU377673), Rice tungro bacilliform virus (RTBV, NP_056762), Rudbeckia flower distortion virus (RFDV, YP_002519387), Soybean chlorotic mottle virus (SbCMV, NP_068729), Strawberry vein banding virus (SVBV, NP_043933), Sweetpotato badnavirus A (SpBA, ACN56746), YP_002916057), Sweetpotato badnavirus B (SpBB, YP_002916057), Sugarcane bacilliform MO virus (SCBMV, YP_595725), Sugarcane bacilliform IM virus (SCBIMV, NP_149413), TaBV (NP_758808), and Tobacco vein clearing virus (TVCV, NP_569141).

Detection of pineapple badnavirus. Specific oligonucleotide sense and antisense primers $5^{\prime}$-TTGGTGATGCCTTTTGGG-3' and $5^{\prime}$-CCTTCCATACATCCGTCCG-3' with an amplicon size of $563 \mathrm{bp}$ were designed from regions shared by PBCOV-HI1 and variant $\mathrm{A}$, based on sequence data available at the time. PCR assay reactions consisted of $6 \mu \mathrm{l}$ of DNA template, $14 \mu \mathrm{l}$ of $2 \times$ Immomix red (Bioline), $8 \mu \mathrm{l}$ of water and $0.5 \mu \mathrm{l}$ of each primer $(15 \mu \mathrm{M}$ concentration). Initial denaturation at $95^{\circ} \mathrm{C}(7 \mathrm{~min})$ was followed by 42 cycles of $95^{\circ} \mathrm{C}(1 \mathrm{~min}), 60^{\circ} \mathrm{C}(1 \mathrm{~min})$, and $72^{\circ} \mathrm{C}(1 \mathrm{~min})$, and a final extension at $72^{\circ} \mathrm{C}$ for $10 \mathrm{~min}$ in a GeneAmp PCR System 2700 (Applied Biosystems). Amplicons were visualized in 2\% agarose gels stained with ethidium bromide.

Field sampling. Field surveys of 4-month-old pineapple plant crops were conducted from years 2007 to 2009, at Dole Food Company on Oahu, Hawaii. Two pineapple hybrids, 'PRI 73-114', imported from the Philippines and Costa Rica, and 'PRI 73-50' were screened for the presence of PBCOV-HI1 and variant A. In total, 100 leaf samples were collected in groups of 20 from each pineapple hybrid and source. Samples consisted of the third leaf from the central portion of the plant. Two locations planted with each hybrid were sampled.

Mealybug transmission trials. Gray pineapple mealybugs (GPM), Dysimcoccus neobrevipes (Beardsley), were established on kabocha squash as previously described (35). Pineapple crowns of PRI 73-114 were dipped in fungicide and insecticide and planted in soil in insect-proof cages. Crowns were tested at the time of planting with PBCOV-HI1- and variant A-specific PCR assays. Crowns testing PBCOV-HI1 free by PCR were placed in three separate cages. Approximately 1,000 mixed-aged GPM were lightly brushed from squash onto three 6-month-old pineapple plants that had tested positive for PBCOV-HI1 in two independent PCR assays, and three plants that had tested negative for PBCOV-HI1 in three independent PCR assays. These plants were each wrapped in drapery sheer fabric and tied shut and placed in water pans, and the PBCOV-HI1-free plants were moved to a separate facility. After 33 days, 10 leaves, each containing approximately 25 to 50 mixedaged GPM, were pulled out of a PBCOV-HI1-negative plant and placed on five PBCOV-HI1-negative crown-derived plants. These five plants were caged together. The mealybug transfer process from the remaining two PBCOV-HI1-negative plants was repeated as described for 10 additional crown-derived PBCOV-HI1-free plants. The next day, the procedure was repeated for mealybugs given a 34-day access feeding to the PBCOV-HI1-infected plants, resulting in three sets of five plants for transmission trials. The nonviruliferous and viruliferous mealybug trials were maintained at separate facilities under similar conditions. 


\section{Results}

PBCOV genome characterization. The 7,451-bp dsDNA genome of a new badnavirus, putatively designated PBCOV-HI1, was determined (accession number GQ398110). The original sequence submitted to GenBank in 2009 was updated in January 2010 to reflect the removal of a glycine, arginine, phenylalanine (GRF) zinc-finger motif annotation and a misaligned splicing area that was the result of a palindrome-like sequence that is not part of the virus. The current accession, GQ398110, published in GenBank reflects this correction. Three putative ORFs were identified and numbered following the convention used for other pararetroviral genomes, starting at the putative plant initiator tRNA ${ }^{\mathrm{MET}}$-binding site. A UTR precedes ORF1 and contains the tRNA ${ }^{\text {MET }}$-binding sequence ...TGGTATCAGAGCA... shared by characterized badnaviruses. ORF1 comprises 171 residues encoding a 20-kDa protein of unknown function that contains the conserved residues identified in pfam 07028 (DUF1319) shared in the orthologous ORFs of other badnaviruses. ORF 2 comprises 132 residues and encodes a putative protein of $15 \mathrm{kDa}$. ORF3 comprises 1,826 residues putatively encoding a polyprotein of $211 \mathrm{kDa}$ that contains regions consistent with those of a movement protein, aspartyl protease, RT, and RNase H. A GRF zinc-finger motif also is detected in BLASTP but the region lacks the conserved GRF residues and is considered a nonspecific hit. Following ORF3 is a 479-nucleotide (nt) UTR containing a putative TATA box encoded by TATATAA at nucleotides 7,376 to 7,383 . The amino acid identity between ORF1, ORF2, and ORF3 of PBCOV-HI1 and other characterized badnaviruses was 20 to $80 \%$, with the highest identity shared with PBCOV from the Zhangjiang district, Guangdong province, China (Table 1).

Nine badnavirus-like variants were also identified. Multiple variants were often present in a host plant. A 2,864-nt contig, identified in this study as PBCOV-HI1 variant A (accession number GQ395793), encodes an aspartyl protease, RT, and RNase H, and contains $390 \mathrm{nt}$ of the UTR following ORF3. Variants B to E (accessions GQ395795 to GQ395798, respectively) are 1,604 to $1,619 \mathrm{nt}$ in length and include the putative active, nucleic acid, and NTP-binding regions in the RT region as well as the first $270 \mathrm{nt}$ of the UTR following ORF3. Variants F to I (accessions GQ395799 to GQ395802, respectively) are 600-nt contigs that span the RT region. These nine variants share $>92 / 95 \%$ (nucleotide/amino acid) identity with the PBCOVs from Hawaii.

Sequence comparisons were also made between PBCOVs from Hawaii identified in this study, 10 partial sequence contigs of putative pineapple badnaviruses identified in Australia (6), and a PBCOV identified in China (42). Contig size of the accessions from Australia limited the comparisons to the $3^{\prime}$ ORF3 regions spanning the highly conserved RT and RNase H domains. Shared nucleotide identities were 64 to $97 \%$ and amino acid identities were 72 to $99 \%$ (Table 2). Nucleotide identity between the fulllength PBCOV from China and PBCOV-HI1 was $90 \%$.

Endogenous pararetrovirus sequences. A 4,012-nt contig, putatively identified in this study as an A. comosus endogenous pineapple pararetrovirus sequence-HI1 (ePBCOV-HI1; GQ395780), and nine similar 600-nt contigs identified in this study as ePBCOV-HI1

Table 1. Amino acid identity of open reading frame (ORF)1, ORF2, and ORF3, for Pineapple bacilliform CO virus-H1 with other badnaviruses

\begin{tabular}{lccc}
\hline Virus & ORF1 & ORF2 & ORF3 \\
\hline Banana streak GF virus & 54 & 36 & 48 \\
Banana streak OL virus & 49 & 31 & 52 \\
Banana streak MY virus & 48 & 35 & 48 \\
Bougainvillea chlorotic vein banding virus & 20 & 23 & 40 \\
Cacao swollen shoot virus & 27 & 31 & 43 \\
Citrus mosaic virus & 30 & 32 & 44 \\
Commelina yellow mottle virus & 43 & $\ldots$ & 44 \\
Cycad leaf necrosis virus & 41 & 31 & 50 \\
Dioscorea bacilliform virus & 32 & 29 & 45 \\
Draceana mottle virus & 41 & 31 & 52 \\
Kalanchoë top-spotting virus & 36 & 33 & \\
Lucky bamboo bacilliform virus & 41 & 31 & \\
Pineapple bacilliform CO virus (China) & 60 & 47 & 51 \\
Sugarcane bacilliform IM virus & 41 & 33 & \\
Sugarcane bacilliform MO virus & 43 & 35 & \\
Sweetpotato badnavirus A & 29 & 33 & 40 \\
Sweetpotato badnavirus B & 30 & 31 & \\
Taro bacilliform virus & 27 & $\ldots$ & 56 \\
\hline
\end{tabular}

Table 2. Nucleotide and amino acid identities shared between Pineapple bacilliform CO virus-HI1 (PBCOV-HI1) and PBCOV variants A to I identified from commercial pineapple in Hawaii, PBCOV characterized in China (NC_014648), and the contigs previously identified in pineapple from Australia

\begin{tabular}{|c|c|c|c|c|c|c|c|c|c|c|c|c|}
\hline \multirow[b]{2}{*}{ ID $^{\mathbf{b}}$} & \multirow[b]{2}{*}{ Accession } & \multirow[b]{2}{*}{ Region $^{c}$} & \multicolumn{10}{|c|}{ PBCOV or variant, nucleotide/amino acid identity $(\%)^{\mathrm{a}}$} \\
\hline & & & H1 & $\mathbf{A}$ & B & C & D & $\mathbf{E}$ & $\mathbf{F}$ & G & H & I \\
\hline PBCOV & NC_014648 & $\mathrm{RT} \rightarrow \mathrm{RNaseH}$ & $96 / 98$ & $96 / 99$ & $96 / 99$ & $95 / 98$ & $96 / 98$ & $95 / 97$ & $95 / 98$ & $95 / 98$ & $95 / 97$ & $95 / 96$ \\
\hline PBCOV & EU377664 & $\mathrm{RT}$ & $83 / 96$ & $84 / 96$ & $83 / 96$ & $83 / 95$ & $83 / 95$ & $81 / 93$ & $84 / 96$ & $82 / 95$ & $83 / 96$ & $83 / 94$ \\
\hline PBCOV & EU377667 & RT & $8 / 94$ & $81 / 93$ & $81 / 93$ & $81 / 92$ & $80 / 91$ & $79 / 90$ & $81 / 93$ & $80 / 91$ & $81 / 93$ & $81 / 92$ \\
\hline PBCOV & EU377669 & RT & $87 / 98$ & $88 / 98$ & $86 / 98$ & $85 / 98$ & $86 / 96$ & $84 / 95$ & $88 / 98$ & $86 / 97$ & $87 / 98$ & $87 / 96$ \\
\hline PBCOV & EU377671 & RT & $83 / 96$ & $83 / 97$ & $83 / 96$ & $81 / 96$ & $81 / 95$ & $80 / 93$ & $83 / 97$ & $81 / 95$ & $83 / 06$ & $82 / 94$ \\
\hline PBErV & EU377672 & $\mathrm{RT}$ & $71 / 82$ & $72 / 82$ & $71 / 81$ & $72 / 81$ & $71 / 79$ & $70 / 78$ & $72 / 83$ & $72 / 80$ & $71 / 82$ & $71 / 81$ \\
\hline PBCOV & EU377666 & $\mathrm{RT} \rightarrow \mathrm{RNaseH}$ & $97 / 98$ & $97 / 99$ & $97 / 99$ & $97 / 98$ & $97 / 98$ & $97 / 97$ & $96 / 99$ & $97 / 99$ & $96 / 98$ & $96 / 97$ \\
\hline PBErV & EU377673 & $\mathrm{RT} \rightarrow \mathrm{RNaseH}$ & $67 / 72$ & $67 / 72$ & $64 / 72$ & $64 / 72$ & $65 / 73$ & $64 / 72$ & $71 / 81$ & $71 / 80$ & $70 / 80$ & $71 / 80$ \\
\hline PBCOV & EU377665 & $\mathrm{RNase} H \rightarrow$ end & $77 / 84$ & $77 / 84$ & $79 / 84$ & $81 / 84$ & $81 / 85$ & $80 / 93$ & NSR & NSR & NSR & NSR \\
\hline PBCOV & EU377668 & $\mathrm{RNaseH} \rightarrow$ end & $78 / 86$ & $78 / 86$ & $80 / 86$ & $81 / 85$ & $81 / 86$ & $80 / 85$ & NSR & NSR & NSR & NSR \\
\hline PBCOV & EU377670 & $\mathrm{RNaseH} \rightarrow$ end & $85 / 92$ & $85 / 92$ & $85 / 92$ & $86 / 93$ & $87 / 93$ & $86 / 92$ & NSR & NSR & NSR & NSR \\
\hline
\end{tabular}

${ }^{\text {a }} \mathrm{NSR}=$ no shared region

b GenBank identifier.

${ }^{\mathrm{c}}$ Region available: $\mathrm{RT}=$ reverse transcriptase, $\mathrm{RT} \rightarrow \mathrm{RNaseH}=$ region spanning $\mathrm{RT}$ to $\mathrm{RNaseH}$, and $\mathrm{RNaseH} \rightarrow \mathrm{end}=\mathrm{region}$ spanning $\mathrm{RNaseH}$ to end of open reading frame 3 . 


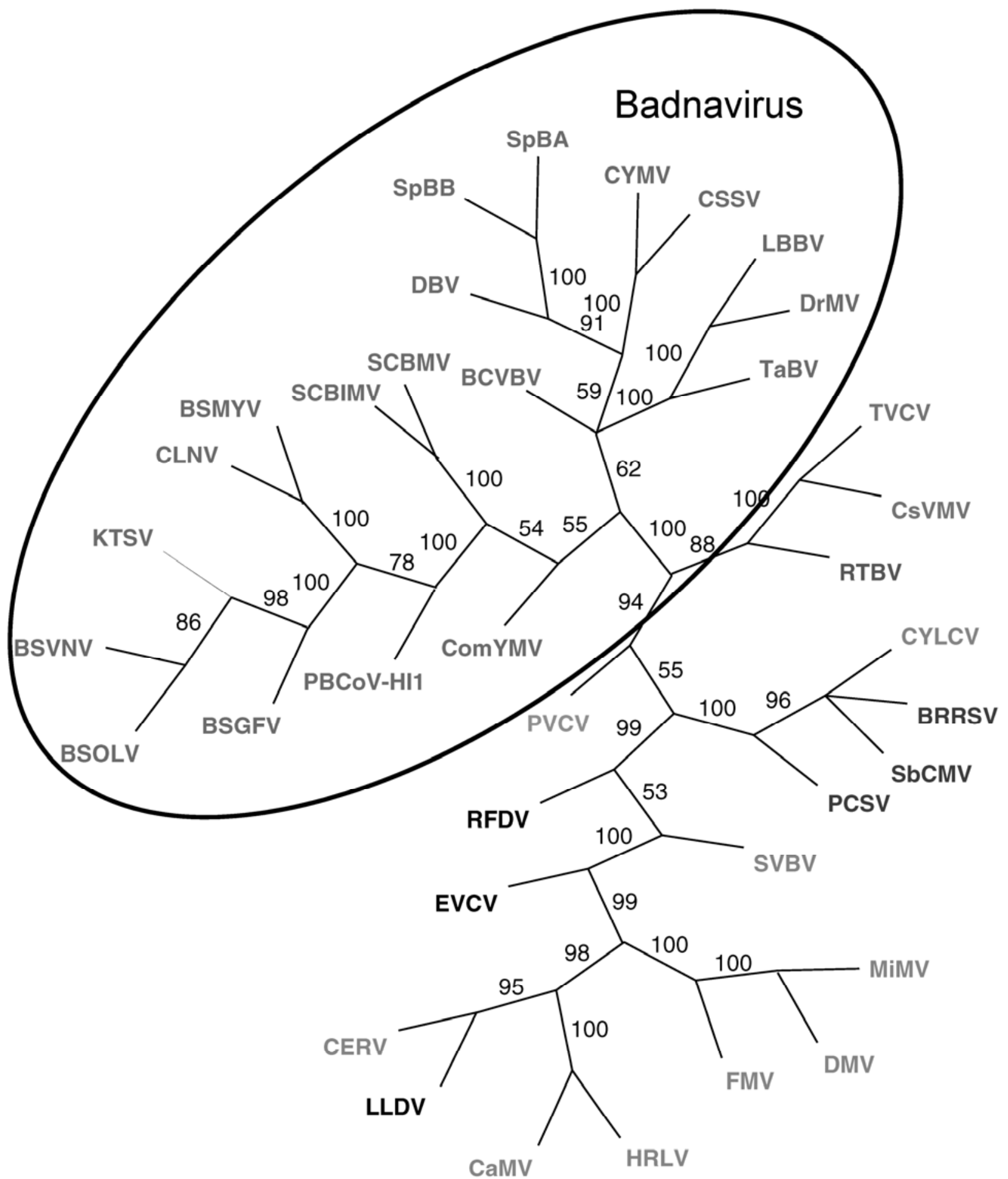

Fig. 1. Boot-strapped, phylogenetic tree created with distance analyses using open reading frame (ORF)3 and orthologs from family Caulimoviridae members show that Pineapple bacilliform CO virus-HI1 (PBCOV-HI1) is firmly embedded in the genus Badnavirus and branches with the type species, Commelina yellow mottle virus. Viruses included in the phylogenetic analyses are Banana streak VN virus (BSVNV, YP_233110), Banana streak MY virus (BSMYV, YP_224289), Banana streak GF virus (BSGFV, YP_233107), Banana streak OL virus (BSOLV, NP_056728), Blueberry red ringspot virus (BRRSV, NP_395469), Bougainville chlorotic vein banding virus (BCVBV, YP_002321513), Cacao swollen shoot virus (CSSV, NP_041734), Cassava vein mosaic virus (CsVMV, NP_056848), Carnation etched ring virus (CERV, NP_612577), Cauliflower mosaic virus (CaMV, NP_056728), Cestrum yellow leaf curling virus (CYLCV, NP_861410), Citrus yellow mosaic virus (CYMV, NP_569153), Commelina yellow mosaic virus (ComYMV, NP_039820), Cycad leaf necrosis virus (CLNV, YP_002117531), Dahlia mosaic virus (DMV, ABW81763), Dracaena mottle virus (DrMV, YP_610965), Eupatorium vein clearing virus (EVCV, YP_001931967), Figwort mosaic virus (FMV, NP_619548), Horseradish latent virus (HRLV, AAW56089), Kalanchoë top-spotting virus (KTSV NP_777317), Lamium leaf distortion virus (LLDV, YP_001931961), Lucky bamboo bacilliform virus (LBBV, YP_001293182), Mirabilis mosaic virus (MiMV, NP_659397), Peanut chlorotic streak virus (PCSV, NP_042513), Petunia vein clearing virus (PVCV, NP_127504), PBCOVs (YP_003987456; EU377666, EU377664, EU377669, EU377671, EU377667, and EU377672), Pineapple bacilliform ER viruses (PBErV, EU377672 and EU377673), Rice tungro bacilliform virus (RTBV, NP_056762), Rudbeckia flower distortion virus (RFDV, YP_002519387), Soybean chlorotic mottle virus (SbCMV, NP_068729), Strawberry vein banding virus (SVBV, NP_043933), Sweetpotato badnavirus A (SpBA, ACN56746), YP_002916057), Sweetpotato badnavirus B (SpBB, YP_002916057), Sugarcane bacilliform MO virus (SCBMV, YP_595725), Sugarcane bacilliform IM virus (SCBIMV, NP_149413), Taro bacilliform virus (TaBV NP_758808), and Tobacco vein clearing virus (TVCV, NP_569141). 
variants A to I (GQ395781 to GQ395789, respectively), were identified from total plant DNA but not DNA from purified virus. The putative endogenous pararetroviral sequences were named based on the nomenclature proposed by Staginnus et al. (41) and Geering (9). This group shared $>95 \%$ amino acid identity in the RT region. ePBCOV-HI1 encodes a complete RT and RNase $\mathrm{H}$ region followed by an adenosine/thymidine-rich region. A peptidase region was absent in this contig in the position expected based on badna- and tungroviruses. Several stop codons were present in the 5 ' end. BLASTX analyses of these regions showed the contigs shared 99\% amino acid identity with the partial RT and RNase H sequences for putative endogenous pineapple pararetrovirus (ePPRV-1), and $66 \%$ amino acid identity with endogenous rice tungro bacilliform virus-c (eRTBV-c), eRTBV-b, and a Ty3-gypsy subclass retrotransposon.

Three additional 603-nt contigs encoding a complete RT domain identified from total plant DNA were tentatively identified as ePBCOV-HI2 (GQ395790), ePBCOV-HI2 variant A (GQ395791), and ePBCOV-HI3 (GQ395792) based on the shared amino acid identities with each other and other sequences. BLASTX analyses of the RT domain showed that the contigs were most similar to the partial RT sequences available for ePPRV-1 contigs from Australia. This group of ePBCOVs shared no significant homology with ePBCOVs identified from Australia or with badnavirus sequences identified from pineapple.

Metaviridae-like sequences. A 2,722-nt contig (GQ395778) that contained an RT-LTR region, RNase $\mathrm{H}$ and integrase core regions, and several shorter contigs of $855 \mathrm{nt}$ or less encoding similar RNase $\mathrm{H}$ and integrase regions were also identified (GQ395779). These contigs shared $>90 \%$ homology with each other in overlapping regions. BLASTX comparisons of the complete polyprotein or RT region of the 2,722-nt contig showed highest similarity (79\% amino acid identity) to a partial sequence of an LTR retrotransposable element identified in pineapple (CAA73042) and numerous pol- and gypsy-type hypothetical proteins from several plants, including Oryza, Vitus, Beta, and Solanum spp.

Phylogenetic analyses. The phylogenetic tree created with distance analyses using the complete polyprotein encoded by PBCOV-HI1 ORF3 and orthologs from Caulimoviridae members show that PBCOV-HI1 is firmly embedded in the Badnavirus genus (Fig. 1). Within the Badnavirus genus, two distinct branches

Table 3. Oligonucleotide primers used to detect and differentiate Pineapple bacilliform $\mathrm{CO}$ virus (PBCOV) and variants; putative endogenous pararetrovirus sequences (ePBCOV)-H1, ePBCOV-H2, and ePBCOV-H3; and putative Ananas Metaviridae-like long terminal repeat sequences identified in pineapple in Hawaii

\begin{tabular}{llc}
\hline Target & \multicolumn{1}{c}{ Sequence 5' to 3' } & Strand \\
\hline PBCOV-HI1 & AAATGCACCAGCGGTCTT & + \\
& BCCTTCCATACATCCRTCCG & - \\
ePBCOV-HI1 & AAATGCACCAGCGGTCTT & + \\
& GGTAATTCAGATACDAGGGS & - \\
ePBCOV-HI2 and -HI3 & ATGCACCTTCAGTATTCC & + \\
& TGGAAGTTTAGATACTAAAGAT & - \\
Ananas-Metaviridae & GCCCCYGCAGCATTYATGGAY & + \\
& AKYYGGYAAGGCAAGYAC & - \\
\hline
\end{tabular}

were formed. PBCOVs were placed on the branch that included the type member, ComYMV, the BSVs, SBVs, KTSV, and CLNV. The other branch included the badnaviruses TaBV, DMV, BCVBV, CSSV, CYMV, DBV, SBV-A, and SBV-B. This branch also included Lucky bamboo virus, which is presently considered an unclassified Caulimovirus. Cestrum yellow leaf curling virus (CYLCV), and the Soymoviruses, Blueberry red ringspot virus and Soybean chlorotic mottle virus formed an indiscernible polytomy. Rudbeckia flower distortion virus and Eupatorium vein-clearing viruses branched with the caulimoviruses.

Specific PCR assays. PCR assays were developed that could detect and distinguish the four groups of sequences identified in this study: PBCOV-HI1 and variants, ePBCOV-H1, ePBCOV-H2 and $\mathrm{H} 3$, and Ananas-Metaviridae-like LTR retroelements (Table 3; data not shown). The PBCOV PCR primers designed are also predicted to detect the PBCOV identified in China.

PBCOV detection and field surveys. Two pineapple hybrids were used for the badnavirus field surveys. PCR assays were used to screen for PBCOV-HI1 and variant A and for putative endogenous pararetroviral sequences (Table 4). The presence of badnavirus-like particles in plants testing positive for PBCOV-HI1 was confirmed with electron microscopy in 10 randomly selected positive plants used for purification. PBCOV incidences in PRI 73-114 imported to Hawaii from Costa Rica and the Philippines in 2003 and 2004 were 63 and $68 \%$, respectively. Putative pararetroviral sequences were detected in $76 \%$ of the plants. The incidences of PBCOV-HI1 in PRI 73-50 was 34\%, and endogenous pararetroviral sequences were detected in $100 \%$ of the plants. Symptoms of virus infection were not observed in the plant that were assayed.

Mealybug transmission. GPM transmitted PBCOV-HI1 to $12 / 15$ plants $(80 \%)$ based on PCR screening of the plants prior to viruliferous mealybug exposure and 60 days after mealybug exposure. PBCOV-HI1 was detected in 1 of 15 plants from the virusfree control trials 60 days after exposure to GPM that were given access to plants that tested free of PBCOV prior to mealybug acquisition.

\section{Discussion}

This study reports the first complete nucleotide sequence of a badnavirus from pineapple in Hawaii. Sequence comparisons in the RT and RNaseH regions show that PBCOV-HI1 shares 98\% identity with a PBCOV characterized in China (NC_014648) (42) and a partial badnavirus sequence characterized in Australia (EU377666). Such high identity in the RT and RNaseH regions suggests that PBCOV-HI1 and the variants identified in this study are likely strains or variants of the PBCOV characterized in China and a partial sequence from Australia, though amino acid identities for ORF1, ORF2, and ORF3 range from 47 to $80 \%$ with the PBCOV characterized in China. Based on identities of the RT and $\mathrm{RNaseH}$ regions, the variants identified in Hawaii are closely related. Comparisons between the badnavirus variants from Hawaii and from Australia (5) show that diversity is present in the pineapple badnaviruses. Similar diversity has been reported in BSV, SBV, TaBV, and others $(1,9,12,44)$.

GPM can transmit PBCOV-HI1 and variant $\mathrm{A}$ in Hawaii. In these repeated experiments, $80 \%$ of the plants exposed to viruliferous mealybugs developed infections but 1 of the 15 plants that

Table 4. Incidence of Pineapple bacilliform CO virus-H1 or variant A (PBCOV-HI1) and putative endogenous pararetrovirus sequences (ePBCOV)-H1, ePBCOV-H2, and ePBCOV S-H3 present in commercially grown pineapple hybrids 'PRI-73-114' imported from the Philippines (P) or Costa Rica (CR) and 'PRI-73-50' in Hawaii

\begin{tabular}{|c|c|c|c|c|c|c|c|c|c|c|c|}
\hline \multirow[b]{3}{*}{ Hybrid } & \multicolumn{11}{|c|}{ Incidence $(\%)^{\mathrm{a}}$} \\
\hline & \multirow[b]{2}{*}{ PBCOV } & \multicolumn{2}{|c|}{ ePBCOV- } & \multicolumn{4}{|c|}{ PBCOV \& ePBCOV- } & \multirow{2}{*}{$\frac{\text { Total with }}{\text { PBCOV }}$} & \multicolumn{3}{|c|}{ Total with ePBCOV- } \\
\hline & & H1 & H2/H3 & H1 & H2/H3 & H1, H2/H3 & H1, H2/H3-free & & H1 & H2/H3 & H1, H2/H3 \\
\hline $73-114 \mathrm{CR}$ & 15 & 1 & 22 & 2 & 41 & 10 & 9 & 68 & 13 & 73 & 76 \\
\hline 73-114 P & 20 & 2 & 31 & 0 & 36 & 7 & 4 & 63 & 9 & 74 & 76 \\
\hline $75-53$ & 0 & 66 & 0 & 3 & 31 & 0 & 0 & 34 & 69 & 31 & 100 \\
\hline
\end{tabular}

a Percentage based on 100 plant samples per hybrid. 
were exposed to nonviruliferous mealybugs became infected. This may have been the result of viruliferous mealybugs coming into contact with the plant, or the plant was infected but below the detection threshold during the initial preexposure screening. Either scenario is possible. Under the second scenario, $80 \%$ may be an overestimate of the transmission rate under our test conditions. If we assume equal distribution of low-titer infections missed during the prescreening, than 1 of 15 plants $(7 \%)$ in the three repetitions that were exposed to viruliferous mealybugs may have been infected prior to the studies. We did not conduct studies with other mealybug species, but Gambley (5) found a 20 and 10\% infection incidence in Australia with the Australian PBCOV and pink pineapple mealybug (D. brevipes) and Planacoccus citri, respectively. We also identified three distinct groups of putative ePBCOVs (ePBCOV-HI1, ePBCOV-HI2, and ePBCOV-HI3) that encode complete RT and RNase $\mathrm{H}$ regions. The ePBCOV sequences were not identified from DNA obtained from purified virus. The designation ePBCOV follows the previously suggested nomenclature for putatively endogenous pararetroviral sequences $(8,36)$. Such endogenous pararetroviruses have been identified in a growing number of tropical and temperate crops $(5,7,10,17,20,40)$. The lack of close homology between the ePBCOV-HI2 group and the PBCOV-HI1s and badnavirus-like sequences from Australia (5) and China (42) suggest these sequences may be from a distant badnavirus ancestor or from a pararetrovirus not yet identified in pineapple. Genomic sequencing of pineapple and further analyses of the pol gene will allow for the localization and further characterization of these endogenous coding sequences and other possible endogenous pararetroviral lineages that have evolved in clonally propagated pineapple.

The characteristics of the conserved motifs from our Ananasderived LTR-type retrotransposons, the BLASTX comparisons with those identified previously in Australia $(5,40)$, and the RTbased phylogenetic analyses suggest they are putative members of the family Metaviridae, and are putatively identified as Ananas LTR-retrotransposons. It cannot be ascertained with certainty if the Ananas Metaviridae-like retrotransposons we identified are located within pericentrometric heterochromatin. The sequencing of the pineapple genome will facilitate localizing the Ananas Metaviridae-like retrotransposons identified in this study.

The diversity, distribution, and incidences of badnaviruses were determined in the commercial pineapple hybrids PRI 73-114 and PRI 73-50. The clonal propagation of pineapple material and the mealybug transmissibility of PBCOV will likely perpetuate and increase the incidence of the viruses in pineapple. The presence of PBCOV was not associated with symptoms in the plants, though yield and other physiological traits such as fruit quality were not accessed. The lack of symptoms complicates selecting propagation sources. The reliable PCR assays developed during this study can detect and distinguish PBCOV, putative ePBCOVs, and Ananas Metaviridae-like retroelements. These assays may be useful for screening of pineapple germplasm used for propagation or breeding.

\section{Acknowledgments}

The research was funded, in part, by grants from the United States Department of Agriculture (USDA) Cooperative State Research, Education and Extension Service T-STAR program agreement numbers 2005-34135-15964 and 2008-34135-19404 and a specific cooperative grant agreement number 58-53205-785 between the USDA Agricultural Research Service Pacific Basin Agricultural Research Center and the University of Hawaii at Manoa. We thank the reviewers for their helpful suggestions to improve this manuscript.

\section{Literature Cited}

1. Bouhida, M., Lockhart, B. E., and Olszewski, N. E. 1993. An analysis of the complete sequence of a sugarcane bacilliform virus genome infectious to banana and rice. J. Gen. Virol. 74:15-22.

2. Brunt, A. A., Crabtree, K., and Gibbs, A. 1990. Pages 242-243 in: Viruses of Tropical Plants. CAB International, Wallington, UK.

3. Eickbush, T., Boeke, J. D., Sandmeyer, S. B., and Voytas, D. F. 2005. Family Metaviridae. Pages 409-420 in: Eight Rep. Int. Committee on Taxonomy of Viruses. C. M. Fauquet, M. A. Mayo, J. Maniloff, U. Desselberger, and L. A. Ball, eds. Elsevier Academic Press, San Diego, CA.
4. Fauquet, C. M., Mayo, Maniloff, J., Desselberger, U., and Ball, L.A. 2005 Virus taxonomy, classification and nomenclature of viruses. Eight Rep. Int Committee on Taxonomy of Viruses. Elsevier Academic Press, San Diego, CA.

5. Gambley, C. F., Geering A. D. W., Steele, V., and Thomas, J. E. 2008 Identification of viral and non-viral reverse transcribing elements in pineapple (Ananas comosus), including members of two new badnavirus species. Arch. Virol. 153:1599-1604.

6. Geering, A. D. W., McMichael, L. A., Dietzgen, R. G., and Thomas, J. E. 2000. Genetic diversity among Banana streak virus isolates from Australia. Phytopathology 90:921-927.

7. Geering, A. D. W., Olszewski, N. E., Harper, G., Lockhart, B. E. L., Hull, R., and Thomas, J. E. 2005. Banana contains a diverse array of endogenous badnaviruses. J. Gen. Virol. 86:511-520.

8. Geering, A. D. W., Scharaschkin, T., and Teycheney, P-Y. 2010. The classification and nomenclature of endogenous viruses of the family Caulimoviridae. Arch. Virol. 155:123-131.

9. Geijskes, R. J. , Braithwaite, K. S., Dale, J. L., Harding, R. M., and Smith G. R. 2002 Sequence analysis of an Australian isolate of Sugarcane bacilliform badnavirus. Arch. Virol. 147:2393-2404.

10. Gregor ,W., Mette, M. F., Staginnus, C., Matzke, M. A., and Matzke, A. J. M. 2004. A distinct endogenous pararetrovirus family in Nicotiana tomentosiformus, a diploid progenitor of polyploidy tobacco. Plant Physiol. 134:1191-1199.

11. Hagan, L. S., Jacquemond, M., Lepingle, A., Lot, H., and Tepfer, M. 1993. Nucleotide sequence and genomic organization of cacao swollen shoot virus. Virology 196:619-628.

12. Harper, G., Hart, D., Moult, S., Hull, R., Geering, A., and Thomas, J. 2005. The diversity of Banana streak virus isolates in Uganda. Arch. Virol 150:2407-2420.

13. Hu, J. S., Gonsalves, A., Sether, D. M., and Ullman, D. E. 1993. Detection of pineapple closterovirus, a possible cause of mealybug wilt of pineapple. Acta Hortic. 334:411-416.

14. Hu, J. S., Sether, D. M., and Ullman, D. E. 1996. Detection of pineapple closterovirus in pineapple plants and mealybugs using monoclonal antibodies. Plant Pathol. 45:829-836.

15. Huang, Q., and Hartung, J. S. 2001. Cloning and sequence analysis of an infectious clone of Citrus yellow mosaic virus that can infect sweet orange via Agrobacterium-mediated inoculation. J. Gen. Virol. 82:2549-2558.

16. Hull, R., Geering, A. D. W., Harper, G., Lockhart, B. E. L., and Schoelz, J E. 2005. Family Caulimoviridae. Pages 385-396 in: Eight Rep. Int Committee on Taxonomy of Viruses. C. M. Fauquet, M. A. Mayo, J. Maniloff, U. Desselberger, and L. A. Ball, eds. Elsevier Academic Press, San Diego, CA.

17. Hull, R., Harper, G., and Lockhart, B. 2000. Viral sequences integrated into plant genomes. Trends Plant Sci. 5:362-365.

18. Jaufeerally-Fakim, Y., Khorugdharry, A., and Harper, G. 2006. Genetic variants of Banana streak virus in Mauritius. Virus Res. 115:91-98.

19. Jones, A. T. , McGavin, W. J. , Geering, A. D. W., and Lockhart, B. E. L. 2001. A new badnavirus in Ribes species, its detection by PCR, and its close association with gooseberry vein banding disease. Plant Dis. 85:417-422.

20. Kunii, M., Kanda, M., Nagano, H., Uyeda, I., Kishima, Y., and Sano, Y. 2004. Reconstruction of putative DNA virus from endogenous rice tungro bacilliform virus-like sequences in the rice genome: Implications for integration and evolution. BMC Genomics 5:80.

21. Lockhart, B. E., Menke, J., Dahal, G., and Olszewski, N. E. 2000 Characterization and genomic analysis of tobacco vein clearing virus, a plant pararetrovirus that is transmitted vertically and related to sequences integrated into the host genome. J. Gen. Virol. 81:1579-1585.

22. Lockhart, B. E., Olszewski, N. E., and Swenson, A. S. 2008. Characterization of Cycad leaf necrosis virus, the first badnavirus detected in a gymnosperm. GenBank accession NC_011097, NCBI. http://www.ncbi.nlm.nih.gov/

23. Lockhart, B. E. L., and Olszewski, N. E. 1993. Serological and genomic heterogeneity of banana streak badnavirus: implications for virus detection in Musa germplasm. Pages 105-113 in: Breeding Bananas and Plantain for Resistance to Disease and Pests. J. Ganry, ed. CIRAD in collaboration with INIBAP. Montpellier, France.

24. Lyttle, D. J., Orlolich, D. A., and Guy, P. L. 2011. Detection and analysis of endogenous badnaviruses in New Zealand Flora. AoB Plants. Plr008. doi:10.1093/aobpla/plr008

25. Medberry, S. L., Lockhart, B. E., and Olszewski, N. E. 1990. Properties of Commelina yellow mottle virus's complete DNA sequence, genomic discontinuities and transcript suggest that it is a pararetrovirus. Nucleic Acids Res. 18:5505-5513.

26. Muller, E., and Sackey, S. 2005. Molecular variability analysis of five new complete Cacao swollen shoot virus genomic sequences. Arch. Virol. 150:53-66.

27. Ndowora, T., Dahal, D., LaFleur, D., Harper, G., Hull, R., Olsezewski, N. E., and Lockhart, B. 1999. Evidence that badnavirus infection in Musa can originate from integrated pararetroviral sequences. Virology 255:214-220.

28. Noreen, F. 2005. Epigenetic regulation of endogenous plant pararegulation Ph.D. diss. Universität Basel, Friedrich Miescher-Institute for Biomedical Research Botanical Institute, Plant Health Unit.

29. Odu, B. O., Hughes, J. d'A., Asiedu, R., Ng, N. Q., Shoyinka, S. A., an 
Oladiran, O. A. 2004. Responses of white yam (Dioscorea rotundata) cultivars to inoculation with three viruses. Plant Pathol. 53:141-147.

30. Richert-Pöggeler, K. R., Noreen, F., Schwarzacher, T., Harper, G., and Hohn, T. 2003. Induction of infectious petunia vein clearing (Pararetro) virus from endogenous provirus in petunia. EMBO J. 22:4836-4846.

31. Rothie, H. M., Chapdelaine, Y., and Hohn, T. 1994. Pararetroviruses and retroviruses: a comparative review of viral structure and gene expression strategies. Adv. Virus Res. 44:1-67.

32. Seal, S., and Muller, E. 2007. Molecular analysis of a full-length sequence of a new yam badnavirus from Dioscorea sansibarensis. Arch. Virol. 152:819-825

33. Sether, D. M., Borth, W. B., Melzer, M. J., and Hu, J. S. 2009. Sequence diversity of badnaviruses and retrotransposons in pineapple in Hawaii. (Abstr.) Phytopathology 99:S118.

34. Sether, D. M., and Hu, J. S. 2007. Genetic variants of badnavirus-like sequences from pineapple in Hawaii. (Abstr.) Phytopathology 97:S106.

35. Sether, D. M., Hu, J. S., and Ullman, D. E. 1998. Transmission of pineapple mealybug wilt associated virus by two species of mealybugs (Dysmicoccus spp.). Phytopathology 88:1224-1230.

36. Staginnus, C., Iskra-Caruana, M. L., Lockhart, B., Hohn, T., and RichertPoggeler, K. R. 2009. Suggestions for a nomenclature of endogenous pararetroviral sequences in plants. Arch. Virol. 154:1189-1193.

37. Su, L., Gao, S., Huang, Y., Ji, C., Wang, D., Ma, Y., Fang, R., and Chen, X,
2007. Complete genomic sequence of Dracaena mottle virus, a distinct badnavirus. Virus Genes 35:423-429.

38. Swofford, D. L. 2000. PAUP*: Phylogenetic Analysis Using Parsimony (* and Other Methods). Sinauer Associates, Sunderland, MA.

39. Thompson, J. D., Gibson, T. J., Plewniak, F., Jeanmougin, F., and Higgins, D. G. 1997. The ClustalX windows interface: flexible strategies for multiple sequence alignment aided by quality analysis tools. Nucleic Acids Res. 25:4876-4882.

40. Thomson, K. G., Thomas, J. E., and Dietzgen, R. G. 1998. Retrotransposonlike sequences integrated into the genome of pineapple, Ananas comosus. Plant Mol. Biol. 38:461-465.

41. Wakman, W., Teakle, D. S., Thomas, J. E., and Dietzgen, R. G. 1995. Presence of a clostero-like virus and bacilliform virus in pineapple plants in Australia. Aust. J. Agric. Res. 46:947-958.

42. Wu, L., Ruan, X., Shen, W., Tan, Y., Zhai, G., and Li, H. 2010. Sequencing and analysis of the complete genomic sequence of pineapple bacilliform comosus virus. Sci. Agric. Sin. doi:CNKI:SUN:ZNYK.0.2010-09-027

43. Yang, I. C., Hafner, G. J., Dale, J. L., and Harding, R. M. 2003. Genomic characterization of Taro bacilliform virus. Arch. Virol. 148:937-949.

44. Yang, I. C., Hafner, G. J., Revill , P. A., Dale, J. L., and Harding, R. M. 2003. Sequence diversity of South Pacific isolates of Taro bacilliform virus and the development of a PCR-based diagnostic test. Arch. Virol. 148:19571968. 